\title{
Evaluation of Soil Pollution Levels in Al-Qadisiyah Governorate, Iraq Using Contamination Index and GIS
}

\author{
Marwah M. Al-Khuzaie ${ }^{1,2}$, Khairul Nizam Abdul Maulud ${ }^{1,3^{*}}$ \\ 1 Department of Civil Engineering, Faculty of Engineering \& Built Environment, Universiti Kebangsaan Malaysia, \\ 43600 UKM Bangi, Selangor, Malaysia \\ 2 Civil Engineering Department, College of Engineering, University of Al-Qadisiyah, Al-Qadisiyah, Iraq \\ ${ }^{3}$ Earth Observation Centre, Institute of Climate Change, Universiti Kebangsaan Malaysia, 43600, UKM Bangi, \\ Selangor, Malaysia \\ * Corresponding author's e-mail: knam@ukm.edu.my
}

\begin{abstract}
The precise determination of trace element concentrations in the soil of the Al-Qadisiyah Governorate is part of the Iraqi sedimentary plain is required to eliminate high levels of harmful elements in polluted soils. The soil samples were collected from 28 representative profiles in Al-Shamiyah city. The soil profiles were defined using virtual characterization. In this study, I-geo was used to analyze soil pollution. The goals and destinations of the I-geo readings Contamination of $\mathrm{Cd}, \mathrm{Ni}, \mathrm{Pb}$, and $\mathrm{Zn}$ in various soil strata. I-geo $(\mathrm{Cd})$ generally range from 0.58 to 4.71 , I-geo $(\mathrm{Ni})$ range from 0.09 to 4.07 , I-geo $(\mathrm{Pb})$ ranged range from 0.07 to 2.79 , and I-geo $(\mathrm{Zn})$ ranges from zero to 2.79 , depicting the local differences in I-geo for pollutants in the research area. Suggesting that the research area had been heavily polluted from $\mathrm{Cd}$ in the varied layers of the soils. On the maps pertaining to $\mathrm{Zn}$ and $\mathrm{Pb}$, the majority of the research area was primarily covered in the orange and blue hues, suggesting that a significant portion of the research area was likely to be severely polluted from $\mathrm{Cd}$ and Ni. Moreover, the land cover layouts of $\mathrm{Ni}$ in layers of the soils revealed concentrations rising towards to the western sections, which could be attributed to proximity to a major drain. The results display that its I-geo value of four trace metals generally range from non-pollute to significantly heavily polluted. The I-geo data show significant differences in levels of the $\mathrm{Ni}, \mathrm{Cd}$, $\mathrm{Zn}$, and $\mathrm{Pb}$ in different soils strata. Including these findings, the soil in Al-Shamiya, Al-Qadisiyah Governorate contains high levels of $\mathrm{Cd}, \mathrm{Ni}, \mathrm{Pb}$, and $\mathrm{Zn}$. Industries of fossil fuel combustion, as well as other man-made wastes include agricultural nutrients, soil conditioners, and sludge, particularly, ammonium phosphate pollution in soils. The pollutant load index (PLI) reveals a baseline level of contamination in 28 locations, as well as a decline in soil quality in four others. Finally, assessing the danger of contamination for trace metals utilizing the I-geo and PLI by using the GIS method and multimodal models is a helpful and relevant strategy.
\end{abstract}

Keywords: geo-accumulation index, the pollution load index, trace elements' variation, inverse distance weighted, bayesian kriging.

\section{INTRODUCTION}

Soil degradation is without a doubt one of the world's most pressing environmental issues. As a result of various degradation processes around the world (Ranjani et al., 2021), approximately 6 million hectares of farming fields have become less productive (Cui et al., 2021). For example, the value of Iraqi sediment plains land is decreasing due to a rise in the number of companies and their pollution, urbanization, increasing traffic levels, and even the exploitation of sewage and waste dumps (Bahram et al., 2018). Water erosion, deforestation, salinity, dryland, and compression are all indications of land degradation in Al-Qadisiyah Governorate lowlands, which are part of the Iraqi sedimentary plain (Cui et al., 2018).

Heavy metals in water can be found in two forms: dissolved and particulate. They are considered continuous and permanent pollutants in the 
environment, providing a considerable health risk to many creatures in the ecosystem due to their toxic properties at the concentrations greater than allowed limits, as well as their ability to accumulate. Heavy metals enter the aquatic system by natural and human activities such as forest fires, volcanoes, rock erosion, mining, fossil fuel burning, residential effluents, untreated industrial effluents, wind, rain water, waste incineration, and agricultural operations (Aguilera et al., 2021).

While a water analysis can assist determine the level of heavy metal contamination in rivers, sediments can also be utilized as a pollution indicator. Heavy metals have a high binding affinity, which results in low concentrations in water and large concentrations in sediments (Duan et al., 2018). Numerous pollution indices and measuring techniques are accessible for investigating soils contamination, including geo-accumulation index I-geo and PLI (pollution load index) (Mandour et al., 2021). The majority of studies have concentrated on trace element transport in soil (Fang et al., 2017). Geo is ideal for monitoring and evaluating the found element levels in the soil, since it clearly demonstrates the impact of human actions on trace metals as well as the influence of the found elements on the environmental (Hagmann et al., 2015). Trace element concentrations in soil frequently exceed the background amounts. Both methods were utilized to determine the pollution levels in Al-Qadisiyah soil and bottom sediment (Jiang et al., 2019).

Globalization and uncontrolled agricultural methods have had an influence on natural landscapes and ecosystems (Ju et al., 2019). As a result, assessing the soil contamination necessitates a thorough understanding of the geographical distribution of pollutants (Moorhead et al., 2016). For low-cost soil surveys, a GIS database can offer precise information. GIS databases may also be used to assist in the development of digital elevation models (DEMs), which are used to describe landforms (Schloter et al., 2018). Trace element distribution and concentration must be investigated. This will allow the pollution levels to be assessed as well as the associated environmental and human health consequences to be studied (Usman et al., 2021). Soil hazardous element evaluation and mapping can help in the formulation of the strategies to improve the long-term utilization of soil resources and reduce soil deterioration. In order to lower the elevated amounts of hazardous elements in contaminated soils, proper estimations of concentrations of hazardous elements in the soil, backed by GIS information are required (Awasthi et al., 2017). Estimating the PLI necessitates a series of calculations that take a substantial amount of both effort and time to transform numerous values from the toxic metal data for the soil into a single number that describes the contaminant level (Sinsabaugh et al., 2017). As a consequence, the goals of the study were as follows: (i) utilize the GIS approach to map contamination of soil based on I-geo for four trace elements ( $\mathrm{Ni}, \mathrm{Cd}, \mathrm{Pb}$, and $\mathrm{Zn}$ ) in soil; and (ii) use I-geo and PLI to quantify the risk of contamination for four trace elements in soil (Tapia-Torres et al., 2015).

\section{MATERIALS AND METHODS}

\section{The study area}

The Iraqi sedimentary plain, which is distinguished by a simple slope from the northwest to the south and southeast between longitudes (44042'0 "E) and (44027'0" E) and two latitudes $\left(31045^{\prime} 0\right.$ “N) and (3203'0" N), passes through the Dagharah district, the line $(22 \mathrm{~m})$ through the Al Saniya district, and the line $(24 \mathrm{~m})$ through the Al-Shamiyah district (Figure 1). Summers are hot and dry, while winters are bitterly cold in the study region. Winter is a dry season, with an average annual rainfall of $144 \mathrm{~mm}$.

The flood plain, which encompasses the majority of the governorate $(90.9 \%)$, is produced by the sediments transported across the study area by the Euphrates River and its branches during flood seasons. During the river's dominance, the nearby regions formed longitudinal zones around river lengths and branches known as river shoulders, while fine clay particles gathered in smaller sizes away from river courses to form the AlShamiyah river basins.

The soil is composed of silt, clay, and sand and is commonly silty clay. The fine texture of the soil turns to clay as one moves farther from the river's path. Despite the height difference, there are layers of sandy soil stretching from the river's path to the sides, which are not an impediment to agricultural activities, except that the lack of slope makes the surface drainage of surplus irrigation water difficult, resulting in the salinity problem. 


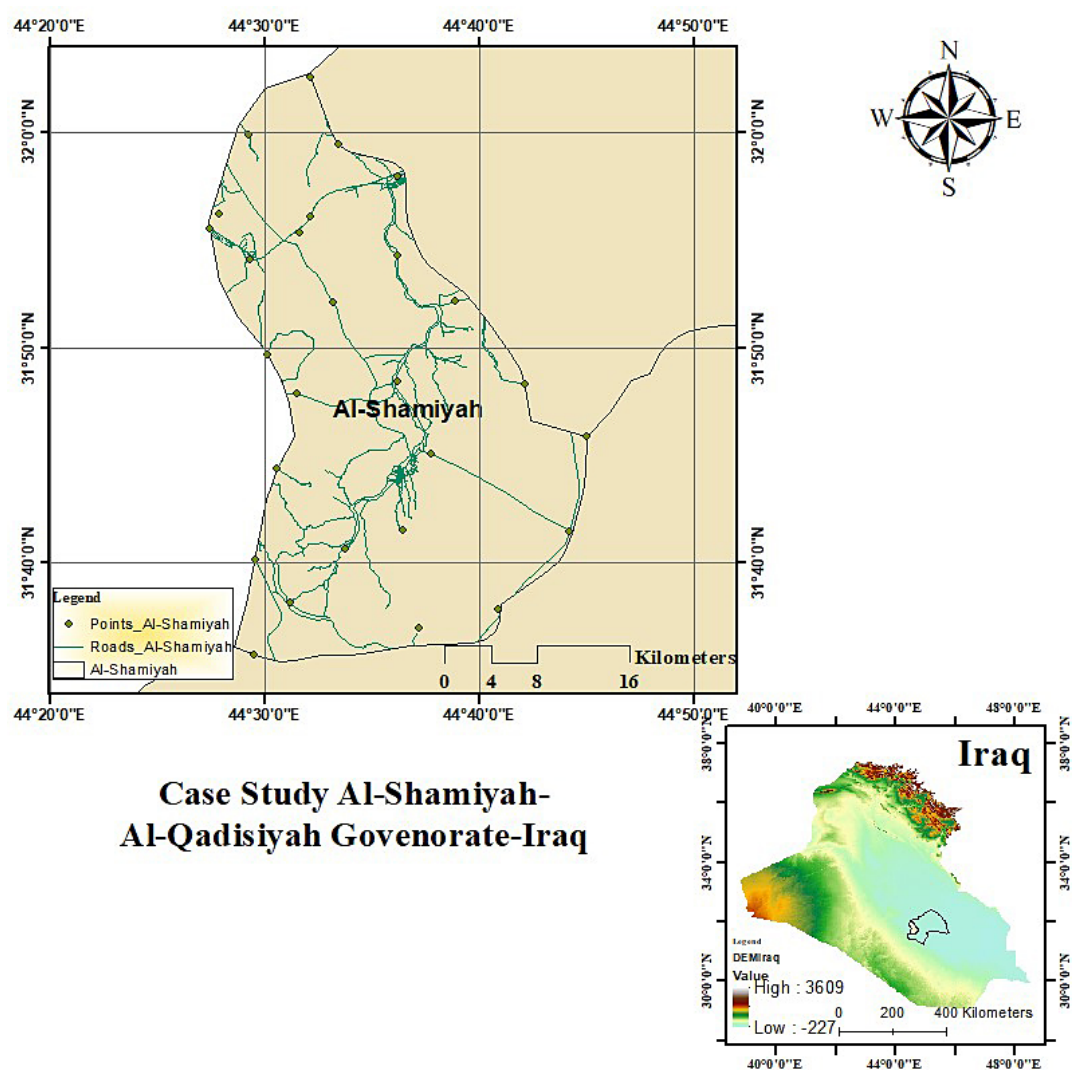

Figure 1. The study area and sampling site locations in Al-Shamiya, Al-Qadisiyah Governorate, Iraq

\section{Soil assessment}

During April 2020, the soil samples were taken from 28 representative profiles in Al-Shamiyah city. Twenty-one soil profiles were chosen based on the study area's geomorphologic units, and the soil samples were taken from different levels based on morphological variances. For the reason that each physiographic unit covers multiple profiles, the distribution degree of certainty is high because it encompasses the physiographic units to a substantial extent (Wahsha et al., 2017). The soil profiles were defined using virtual characterization, and the color grade was determined using the Mansell book.

\section{Contamination evaluation}

\section{Geo-accumulation Index (I-geo)}

The I-geo analyzes pollution by comparing the measured trace element levels to background levels, which were originally intended to evaluate bottom sediments (Wang M. et al., 2017). Using the following equation, the geographic accumulation index (I-geo) was utilized to evaluate the trace element pollution (Hossain Bhuiyan et al., 2021):

$$
I_{\text {geo }}=\log _{2} C_{n} / 1.5 B_{n}
$$

where: $C n$ is the trace element concentration determined in the soil and $B n$ is the geochemical background concentration of the trace element (middle crust) (Wang Y. et al., 2017).

In order to lessen the influence of any variations in background values induced by rocky variations in sediments, the constant 1.5 was introduced to Equation (1). Because soil is a part of the Earth's crust, and its chemical composition is linked to that of the crust, the concentration reached here is comparable to that of the crust's components (Wang et al., 2019). Table 1 shows the I-geo categorization.

\section{The Pollution Load Index (PLI)}

The PLI is a Cif that estimates the total value of all trace elements at a given location using a parametric average of pollution coefficients (Wood et al., 2016). By calculating the metal 
Table 1. The geo-accumulation index (I-geo) classifies, values, and levels of contamination in soil

\begin{tabular}{|c|c|l|}
\hline I-geo class & I-geo value & \multicolumn{1}{|c|}{ Level of contamination } \\
\hline 0 & I-geo $\leq 0$ & Uncontaminated \\
\hline 1 & $0<$ I-geo $<1$ & $\begin{array}{l}\text { Uncontaminated/moderately } \\
\text { contaminated }\end{array}$ \\
\hline 2 & $1<$ I-geo $<2$ & Moderately contaminated \\
\hline 3 & $2<$ I-geo $<3$ & $\begin{array}{l}\text { Moderately/strongly } \\
\text { contaminated }\end{array}$ \\
\hline 4 & $3<$ I-geo $<4$ & Strongly contaminated \\
\hline 5 & $4<$ I-geo $<5$ & $\begin{array}{l}\text { Strongly/extremely } \\
\text { contaminated }\end{array}$ \\
\hline 6 & $5<$ I-geo & Extremely contaminated \\
\hline
\end{tabular}

concentration by the background value equation, the contamination factor $(\mathrm{CF})$ was calculated:

$$
C F=\underline{C}_{\underline{n}} / B_{n}
$$

The pollutant load index (PLI) was created using the equation below (Xian et al., 2015) to calculate the element concentrations in soils in relation to a standard concentration:

$$
P L I=\left(C F_{1} \times C F_{2} \times \ldots \times C F_{n}\right)^{1 / n}
$$

$\mathrm{CF}$ is the contamination factor, and $\mathrm{n}$ is the number of metals. This metric may be used to assess the degree of pollution in the environment in order to enhance soil quality through monitoring. The PLI categorization is shown in Table 2 (Xu et al., 2018).

\section{Spatial distributions of trace elements}

Spatial completion is often when data is present is obtained in multiple areas (such as soil qualities) to offer continuous information (Xian et al., 2015). The ArcGIS Spatial Analyst 10.2.1 update adds spatial data analysis tools for modeling spatially distributed uses statistical theory and methodology. For four trace elements, the interpolation techniques in ArcGIS Spatial Analysis

Table 2. The PLI categorization

\begin{tabular}{|c|c|l|}
\hline PLI class & PLI value & \multicolumn{1}{|c|}{ Level of pollution } \\
\hline 1 & $0<\mathrm{PLI} \leq 1$ & Unpolluted \\
\hline 2 & $1<\mathrm{PLI} \leq 2$ & $\begin{array}{l}\text { Moderately polluted to } \\
\text { unpolluted }\end{array}$ \\
\hline 3 & $2<\mathrm{PLI} \leq 3$ & Moderately polluted \\
\hline 4 & $3<\mathrm{PLI} \leq 4$ & $\begin{array}{l}\text { Moderately to highly } \\
\text { polluted }\end{array}$ \\
\hline 5 & $4<\mathrm{PLI} \leq 5$ & Highly polluted \\
\hline 6 & $5 \leq \mathrm{PLI}$ & Very highly polluted \\
\hline
\end{tabular}

were used to derive the intervening values from data. The weighted inverse distance (IDW) is a form of approximation that considers the values measured around the predicted point. The values gathered closer to the prediction site have a greater impact on the measured value of the distant ones; the closest points to the prediction site are given more weight, with the weight varying with distance (Wood et al., 2016). It is advantageous to use IDW to map the geographic distribution of heavy metals. This interpolation approach works better with uniformly distributed points (Liang et al., 2019). As a result, the number of components in the research is related to the existence of other sources, such as industrial drainage and agricultural irrigation. The statistical correlations between the known sites were found using ArcGIS IDW tool and the amounts of trace elements in the study region were determined. The IDW was used to estimate each grid point with 28 nearby samples. Two strengths were employed to weigh the nearest place, which has a direct influence on the number of components in the soil, which varies with respect to the distance from the source, making this IDW approach preferable.

$$
z\left(x_{0}\right)=\sum_{i=0}^{n} 1^{z(x i)} d i j^{-r} / \sum_{i}^{n} 1^{d i j^{-r}}
$$

where: $x_{0}$ denotes the estimate point and $x i$ denotes the number of data inside a certain area. The weights $(r)$ are related to the difference between the estimate and the data points by $d i j$.

The IDW method has the effect of providing more weight to the data points close to the interpolation point and less weight to the data sets further away. As the weight increases, so do the number of close-to- $x_{0}$ effect points.

\section{RESULTS}

\section{Variation of four trace elements}

This study looked at the pollution of three different soil layers with $\mathrm{Cd}, \mathrm{Ni}, \mathrm{Pb}$, and $\mathrm{Zn}$. The values of the four trace elements varied significantly. Cn denotes the quantity of trace metals detected in soil $(\mathrm{Cn}), \mathrm{Cd}$ ranged from 0.05 to 0.87 , $\mathrm{Ni}$ ranged from 1.70 to $26.90, \mathrm{~Pb}$ ranged from 2.80 to 18.50 , and $\mathrm{Zn}$ ranged from 2.80 to 18.50 . As a result, the trace metals quantities in the soil are listed in ascending order, as shown in Table 


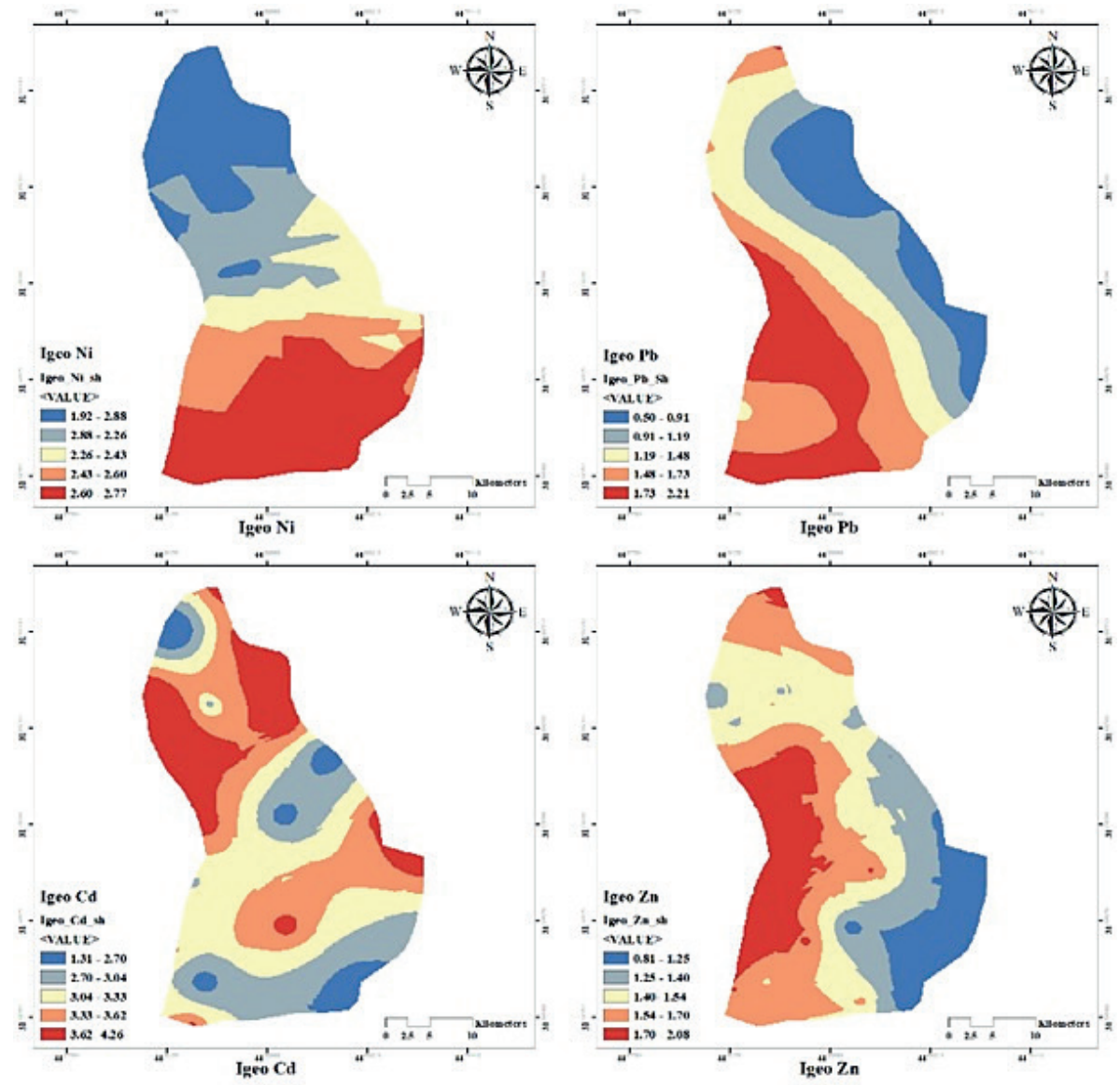

Figure 2. I-geo $(\mathrm{Ni}, \mathrm{Pb}, \mathrm{Cd}, \mathrm{Zn})$ spatial distribution in soils

1 for $\mathrm{Ni}, \mathrm{Pb}, \mathrm{Zn}$, and $\mathrm{Cd}$ (Figure 3) and Figure 2 I-geo $(\mathrm{Ni}, \mathrm{Pb}, \mathrm{Cd}, \mathrm{Zn})$ spatial distribution in soils.

\section{Contamination risk analysis using the geo-accumulation index}

In this study, the I-geo was used to analyze soil pollution. The I-geo readings objectives and destinations $\mathrm{Cd}, \mathrm{Ni}, \mathrm{Pb}$, and $\mathrm{Zn}$ contamination in the various soil strata. (I-geo) $(\mathrm{Cd})$ generally range from 0.58 to 4.71 , (I-geo) (Ni) generally range from 0.09 to 4.07 , (I-geo) $(\mathrm{Pb})$ ranged generally ranged from 0.07 to 2.79 , and I-geo ( $\mathrm{Zn}$ ) ranged from 0 to 2.79, as shown in Table 1 .

Figure 2 depicts the local differences in I-geo for the pollutants in the research area. The blue to orange colors range symbolizes moderately polluted soil associated with the heavy metals investigated, whereas the red color range symbolizes moderately/strongly contaminated soils.

The Cd allocation maps are red, suggesting that the research area had been heavily polluted from $\mathrm{Cd}$ in the varied layers of the soils (Figure 3). On the maps pertaining to $\mathrm{Zn}$ and $\mathrm{Pb}$, the

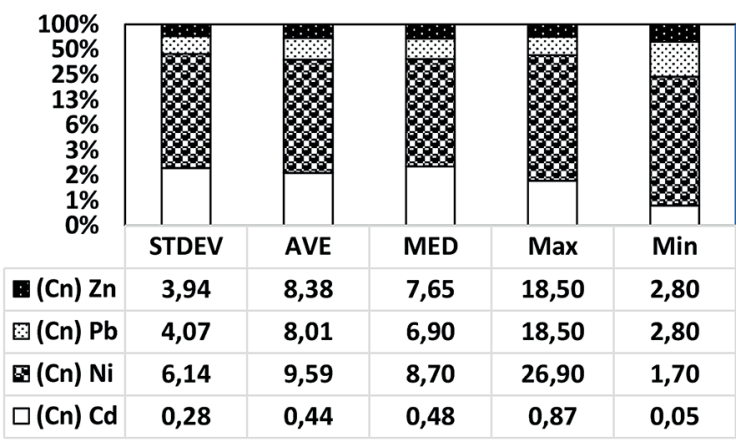

Figure 3. Geo-accumulation $(\mathrm{Cn})$ used for four trace elements

majority of the research area was primarily covered in the orange and blue hues, suggesting that a significant portion of the research area was likely to be severely polluted from $\mathrm{Cd}$ and $\mathrm{Ni}$. Moreover, the land cover layouts of $\mathrm{Ni}$ in layers of the soils revealed the concentrations rising towards to the western sections, which could be attributed to proximity to a major drain (Figure 4).

The graphic shows the distribution of Pollution Load Index encompassing the greatest share 


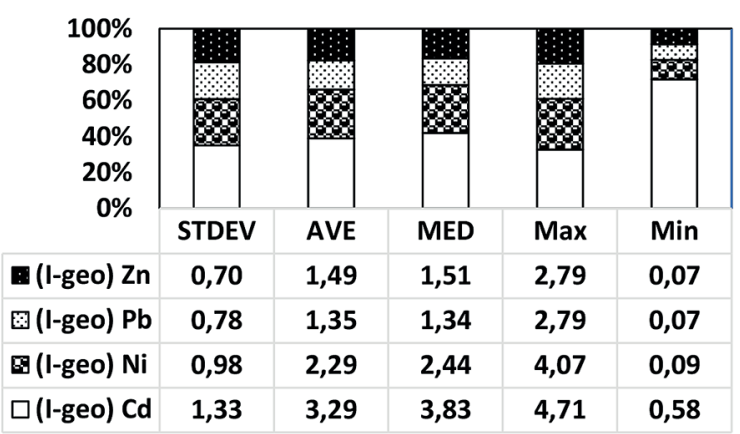

Figure 4. Geo-accumulation index (I-geo) for four trace elements

of moderately polluted areas in blue and gray. The orange and red colors cover a moderate to low percentage of the heavily polluted areas in the research area's west. Empirical Bayesian Kriging is a Kriging-based interpolation approach and inverse distance weighted (IDW) methodology ArcGIS Geostatistical and Researcher and the intervening distance weighted shown in Figure 5.

\section{DISCUSSION}

The results display that its I-geo value of four trace metals generally range from non-polluted to significantly heavily polluted. The I-geo data show significant differences in levels of the $\mathrm{Ni}$, $\mathrm{Cd}, \mathrm{Zn}$, and $\mathrm{Pb}$ in different soils strata (Figure 2).

Including these findings, the soil in AlShamiya, Al-Qadisiyah Governorate contains high levels of $\mathrm{Cd}, \mathrm{Ni}, \mathrm{Pb}$, and $\mathrm{Zn}$. Industries of fossil fuel combustion, and nickel mining, as well as other man-made wastes, including agricultural nutrients, soil conditioners, and sludge., particularly ammonium phosphate, industrial emissions, and inorganic fertilizers, are the primary sources of $\mathrm{Cd}, \mathrm{Ni}, \mathrm{Zn}$, and $\mathrm{Pb}$ pollution in soils (Al-Juboury, 2009).

In Iraq's Al-Qadisiyah Governorate, researchers employed the I-geo and PLI to look at trace pollutants $(\mathrm{Ni}, \mathrm{Cd}, \mathrm{Zn}$, and $\mathrm{Pb})$. The condition of Cd pollution in the different layers of soils suggested that the research area was considerably contaminated. In terms of $\mathrm{Cd}$ and $\mathrm{Ni}$ contamination, the $\mathrm{Zn}$ and $\mathrm{Pb}$ maps revealed that a significant portion of the study area was moderately to severely polluted (Al-Dabbas and Abdullah, 2020). Furthermore, growing concentrations toward the western areas of the spatial variation mapping of $\mathrm{Ni}$ in layers of soils were identified, that may be due to closeness to the drainage system. Four trace element I-geo values revealed the circumstances ranging from non-polluted to badly contaminated. The pollutant load index (PLI) reveals a baseline level of contamination in 28 locations, as well as a decline in soil quality in four others (Radhi et al., 2021).

\section{CONCLUSIONS}

The Al-Shamiya and Al-Qadisiyah drains often absorb substantial volumes of contaminants in water from industrial and home wastewater as well as distributed agricultural drainage. Close attention needs to be given to the Euphrates River,
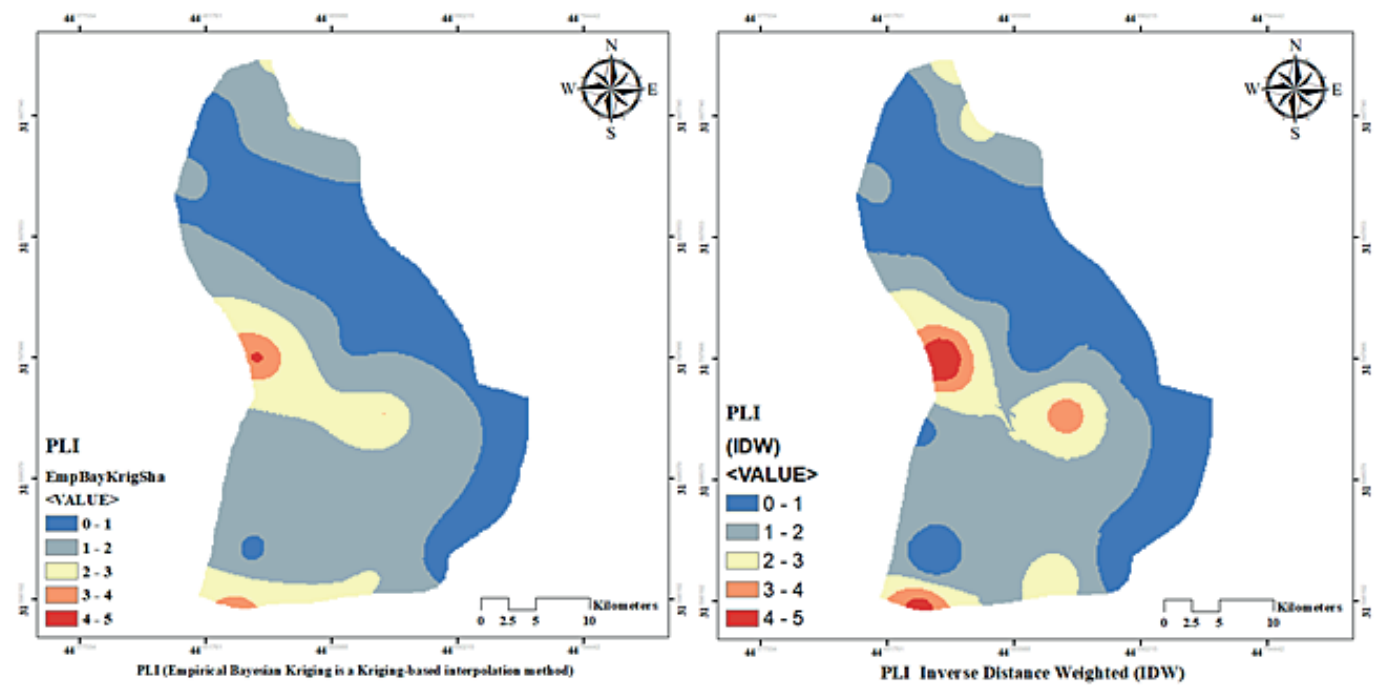

Figure 5. The pollution load index to data for four trace elements were used in the first section Empirical Bayesian Kriging is a Kriging-based interpolation method and used the second section IDW method 
which absorbs enormous amounts of contaminants. The present analysis reveals that the soil and heavy metals may provide an excellent source for the natural contamination by the heavy metals in the metasediments. However, the majority of the contamination comes from the sewage discharged to the river. This was proven by the low quality of water and soil pollution with contaminants in the Shamiya region. It is recommended that the urban and industrial wastewater supplies in the zone be managed before being dumped into the river. Using the soil nutrients classified as hazardous to cultivate rice and maize products for human food may entail health problems.

\section{Acknowledgments}

The authors gratefully acknowledge the Earth Observation Centre, Institute of Climate Change Universiti Kebangsaan Malaysia (UKM), UKM YSD Chair of Sustainability (UKMYSD-2021-003) and Civil Engineering Department, College of Engineering, University of AlQadisiyah, Al-Qadisiyah, Iraq for the support to conduct this study.

\section{REFERENCES}

1. Aguilera A., Bautista F., Gutiérrez-Ruiz M., Ceniceros-Gómez A.E., Cejudo R., Goguitchaichvili A. 2021. Heavy metal pollution of street dust in the largest city of Mexico, sources and health risk assessment. Environ. Monit. Assess., 193. https:// doi.org/10.1007/s10661-021-08993-4

2. Al-Dabbas M.A., Abdullah M.A. 2020. Assessment of soil pollution in the Ishaqi project area- Salah aldean Governorate, Iraq. Iraqi J. Sci., 61, 382-388. https://doi.org/10.24996/ijs.2020.61.2.16

3. Al-Juboury A.I. 2009. Natural pollution by some heavy metals in the Tigris River, Northern Iraq. Int. J. Environ. Res., 3, 189-198. https://doi. org/10.22059/ijer.2009.47

4. Awasthi M.K., Liao R., Ali A., Mahar A., Guo D., Li R., Xining S., Awasthi M.K., Wang Q., Zhang Z. 2017. Spatial distribution and risk assessment of heavy metals in soil near a $\mathrm{Pb} / \mathrm{Zn}$ smelter in Feng County, China. Ecotoxicol. Environ. Saf., 139, 254262. https://doi.org/10.1016/j.ecoenv.2017.01.044

5. Bahram M., Hildebrand F., Forslund S.K., Anderson J.L., Soudzilovskaia N.A., Bodegom P.M., Bengtsson-Palme J., Anslan S., Coelho L.P., Harend H., Huerta-Cepas J., Medema M.H., Maltz M.R., Mundra S., Olsson P.A., Pent M., Põlme S., Sunagawa S., Ryberg M., Tedersoo L., Bork P. 2018.
Structure and function of the global topsoil microbiome. Nature, 560, 233-237. https://doi.org/10.1038/ s41586-018-0386-6

6. Cui Y., Fang L., Guo X., Wang X., Zhang Y., Li P., Zhang X. 2018. Ecoenzymatic stoichiometry and microbial nutrient limitation in rhizosphere soil in the arid area of the northern Loess Plateau, China. Soil Biol. Biochem. 116, 11-21. https://doi. org/10.1016/j.soilbio.2017.09.025

7. Cui Y., Wang X., Wang X., Zhang X., Fang L. 2021. Evaluation methods of heavy metal pollution in soils based on enzyme activities: A review. Soil Ecol. Lett. https://doi.org/10.1007/s42832-021-0096-0

8. Duan C., Fang L., Yang C., Chen W., Cui Y., Li S. 2018. Reveal the response of enzyme activities to heavy metals through in situ zymography. Ecotoxicol. Environ. Saf., 156, 106-115. https://doi. org/10.1016/j.ecoenv.2018.03.015

9. Fang L., Liu Y., Tian H., Chen H., Wang Y., Huang M. 2017. Proper land use for heavy metal-polluted soil based on enzyme activity analysis around $\mathrm{a} \mathrm{Pb}-$ $\mathrm{Zn}$ mine in Feng County, China. Environ. Sci. Pollut. Res., 24, 28152-28164. https://doi.org/10.1007/ s11356-017-0308-4

10. Hagmann D.F., Goodey N.M., Mathieu C., Evans J., Aronson M.F.J., Gallagher F., Krumins J.A. 2015. Effect of metal contamination on microbial enzymatic activity in soil. Soil Biol. Biochem. 91, 291297. https://doi.org/10.1016/j.soilbio.2015.09.012

11. Hossain Bhuiyan M.A., Chandra Karmaker S., Bodrud-Doza M., Rakib M.A., Saha B.B. 2021. Enrichment, sources and ecological risk mapping of heavy metals in agricultural soils of dhaka district employing SOM, PMF and GIS methods. Chemosphere, 263. https://doi.org/10.1016/j. chemosphere.2020.128339

12. Jiang R., Wang M., Chen W., Li X., BalseiroRomero M., Baveye P.C. 2019. Ecological risk of combined pollution on soil ecosystem functions: Insight from the functional sensitivity and stability. Environ. Pollut., 255. https://doi.org/10.1016/j. envpol.2019.113184

13. Ju W., Liu L., Fang L., Cui Y., Duan C., Wu H. 2019. Impact of co-inoculation with plant-growth-promoting rhizobacteria and rhizobium on the biochemical responses of alfalfa-soil system in copper contaminated soil. Ecotoxicol. Environ. Saf., 167, 218-226. https://doi.org/10.1016/j.ecoenv.2018.10.016

14. Liang J., Ding J., Wang J., Wang F. 2019. Quantitative estimation and mapping of soil salinity in the Ebinur Lake wetland based on VIS-NIR reflectance and Landsat 8 OLI data. Acta Pedol. Sin., 56. https:// doi.org/10.11766/trxb201805070182

15. Mandour A., El-Sayed M.K., El-Gamal A.A., Khadr A.M., Elshazly A. 2021. Temporal distribution of trace metals pollution load index in the Nile Delta 
coastal surface sediments. Mar. Pollut. Bull., 167. https://doi.org/10.1016/j.marpolbul.2021.112290

16. Moorhead D.L., Sinsabaugh R.L., Hill B.H., Weintraub M.N. 2016. Vector analysis of ecoenzyme activities reveal constraints on coupled $\mathrm{C}, \mathrm{N}$ and $\mathrm{P}$ dynamics. Soil Biol. Biochem., 93, 1-7. https://doi. org/10.1016/j.soilbio.2015.10.019

17. Radhi A.B., Shartooh S.M., Al-Heety E.A. 2021. Heavy metal pollution and sources in dust from primary schools and kindergartens in Ramadi City, Iraq. Iraqi J. Sci. 62, 1816-1828. https://doi. org/10.24996/ijs.2021.62.6.7

18. Ranjani M., Veerasingam S., Venkatachalapathy R., Mugilarasan M., Bagaev A., Mukhanov V., Vethamony P. 2021. Assessment of potential ecological risk of microplastics in the coastal sediments of India: A meta-analysis. Mar. Pollut. Bull., 163. https://doi. org/10.1016/j.marpolbul.2021.111969

19. Schloter M., Nannipieri P., Sørensen S.J., van Elsas J.D. 2018. Microbial indicators for soil quality. Biol. Fertil. Soils, 54. https://doi.org/10.1007/ s00374-017-1248-3

20. Sinsabaugh R.L., Moorhead D.L., Xu X., Litvak M.E. 2017. Plant, microbial and ecosystem carbon use efficiencies interact to stabilize microbial growth as a fraction of gross primary production. New Phytol., 214, 1518-1526. https://doi.org/10.1111/nph.14485

21. Tapia-Torres Y., Elser J.J., Souza V., García-Oliva F. 2015. Ecoenzymatic stoichiometry at the extremes: How microbes cope in an ultra-oligotrophic desert soil. Soil Biol. Biochem., 87, 34-42. https://doi. org/10.1016/j.soilbio.2015.04.007

22. Usman Q.A., Muhammad S., Ali W., Yousaf S., Jadoon I.A.K. 2021. Spatial distribution and provenance of heavy metal contamination in the sediments of the Indus River and its tributaries, North Pakistan: Evaluation of pollution and potential risks. Environ. Technol. Innov. 21. https://doi. org/10.1016/j.eti.2020.101184

23. Wahsha M., Nadimi-Goki M., Fornasier F., Al-Jawasreh R., Hussein E.I., Bini C. 2017. Microbial enzymes as an early warning management tool for monitoring mining site soils. Catena, 148, 40-45. https://doi.org/10.1016/j.catena.2016.02.021

24. Wang M., Faber J.H., Chen W. 2017. Application of stress index in evaluating toxicological response of soil microbial community to contaminants in soils. Ecol. Indic., 75, 118-125. https://doi.org/10.1016/j. ecolind.2016.12.002

25. Wang Y., Wang R., Fan L., Chen T., Bai Y., Yu Q., Liu Y. 2017. Assessment of multiple exposure to chemical elements and health risks among residents near Huodehong lead-zinc mining area in Yunnan, Southwest China. Chemosphere, 174, 613-627. https://doi.org/10.1016/j.chemosphere.2017.01.055

26. Wang Z., Tian H., Tan X., Wang F., Jia H., Megharaj M., He W. 2019. Long-term As contamination alters soil enzyme functional stability in response to additional heat disturbance. Chemosphere, 229, 471-480. https://doi.org/10.1016/j.chemosphere.2019.05.055

27. Wood J.L., Tang C., Franks A.E. 2016. Microbial associated plant growth and heavy metal accumulation to improve phytoextraction of contaminated soils. Soil Biol. Biochem. https://doi.org/10.1016/j. soilbio.2016.08.021

28. Xian Y., Wang M., Chen W. 2015. Quantitative assessment on soil enzyme activities of heavy metal contaminated soils with various soil properties. Chemosphere, 139, 604-608. https://doi.org/10.1016/j. chemosphere.2014.12.060

29. Xu Y., Seshadri B., Sarkar B., Wang H., Rumpel C., Sparks D., Farrell M., Hall T., Yang X., Bolan N. 2018. Biochar modulates heavy metal toxicity and improves microbial carbon use efficiency in soil. Sci. Total Environ., 621, 148-159. https://doi. org/10.1016/j.scitotenv.2017.11.214 